\title{
Neurosurgery at the epicenter of the COVID-19 pandemic in Indonesia: experience from a Surabaya academic tertiary hospital
}

\author{
Wihasto Suryaningtyas, MD, PhD, Joni Wahyuhadi, MD, PhD, ${ }^{1,2}$ Agus Turchan, MD, PhD, ${ }^{1}$ \\ Eko Agus Subagio, MD, PhD, ${ }^{1}$ Muhammad Arifin Parenrengi, MD, PhD, ${ }^{1}$ Tedy Apriawan, MD,1 \\ Asra Al Fauzi, MD, PhD, ${ }^{1}$ and Abdul Hafid Bajamal, MD, PhD'

\begin{abstract}
${ }^{1}$ Department of Neurosurgery, Universitas Airlangga Faculty of Medicine-Dr. Soetomo Academic General Hospital, Surabaya; and ${ }^{2}$ The COVID-19 Curative Taskforce for The East Java Region, East Java Provincial Government, Surabaya, Indonesia
\end{abstract}

\begin{abstract}
OBJECTIVE Global outbreak of the novel coronavirus disease 2019 (COVID-19) has forced healthcare systems worldwide to reshape their facilities and protocols. Although not considered the frontline specialty in managing COVID-19 patients, neurosurgical service and training were also significantly affected. This article focuses on the impact of the COVID-19 outbreak at a low- and/or middle-income country (LMIC) academic tertiary referral hospital, the university and hospital policies and actions for the neurosurgical service and training program during the outbreak, and the contingency plan for future reference on preparedness for service and education.
\end{abstract}

METHODS The authors collected data from several official databases, including the Indonesian Ministry of Health database, East Java provincial government database, hospital database, and neurosurgery operative case log. Policies and regulations information was obtained from stakeholders, including the Indonesian Society of Neurological Surgeons, the hospital board of directors, and the dean's office.

RESULTS The curve of confirmed COVID-19 cases in Indonesia had not flattened by the 2nd week of June 2020. Surabaya, the second-largest city in Indonesia, became the epicenter of the COVID-19 outbreak in Indonesia. The neurosurgical service experienced a significant drop in cases (50\% of cases from normal days) along all lines (outpatient clinic, emergency room, and surgical ward). Despite a strict preadmission screening, postoperative COVID-19 infection cases were detected during the treatment course of neurosurgical patients, and those with a positive COVID-19 infection had a high mortality rate. The reduction in the overall number of cases treated in the neurosurgical service had an impact on the educational and training program. The digital environment found popularity in the educational term; however, digital resources could not replace direct exposure to real patients. The education stakeholders adjusted the undergraduate students' clinical postings and residents' working schemes for safety reasons.

CONCLUSIONS The neurosurgery service at an academic tertiary referral hospital in an LMIC experienced a significant reduction in cases. The university and program directors had to adapt to an off-campus and off-hospital policy for neurosurgical residents and undergraduate students. The hospital instituted a reorganization of residents for service. The digital environment found popularity during the outbreak to support the educational process.

https://thejns.org/doi/abs/10.3171/2020.9.FOCUS20559

KEYWORDS COVID-19; low- and middle-income countries; neurosurgery; global pandemic

I NDONESIA is one of the low- and/or middle-income countries (LMICs) with the highest number of active cases of the novel coronavirus disease 2019 (COVID-19) and was ranked 32 among 213 countries affected by the pandemic. Since the first reported case in
Indonesia on March 2, 2020, the number of active cases of COVID-19 has grown exponentially. ${ }^{1}$ The pandemic put extra burdens on several areas, including healthcare. The national healthcare system had to adapt to the new situation without any previous experience in facing a global

ABBREVIATIONS COVID-19 = coronavirus disease 2019; DSAGH = Dr. Soetomo Academic General Hospital; ICU = intensive care unit; LMICs = low- and/or middleincome countries; PCR = polymerase chain reaction; PPE = personal protective equipment.

SUBMITTED June 17, 2020. ACCEPTED September 22, 2020.

INCLUDE WHEN CITING DOI: 10.3171/2020.9.FOCUS20559. 
pandemic. In terms of social regulation, the government announced a public health emergency and instituted a semi-lockdown situation to confine the spread of the disease. Several regions with a high number of active cases applied a regulation for large-scale social restrictions..$^{2-4}$ The restrictions included prohibiting mass gatherings, closing schools and nonpublic service offices, curbing nonessential businesses, and limiting public transport. The Indonesian Ministry of Health appointed several hospitals as referral hospitals to manage the emerging infectious disease. The Dr. Soetomo Academic General Hospital (DSAGH) and 10 other hospitals were designated to cover the East Java province. ${ }^{5}$

DSAGH is located in Surabaya, the capital of East Java province, the city with the highest number of active cases in Indonesia. It is a 1500-bed hospital equipped with a full-range intensive care unit (ICU) and isolation wards for infectious diseases, serving as the tertiary referral hospital and main academic affiliation hospital of Universitas Airlangga Faculty of Medicine. As the top referral hospital in the East Java province, it provides high-volume healthcare services for various cases and functions as the main academic affiliation hospital for educational and training centers for undergraduate students, the residency training program of multiple specialties, and the fellowship program. However, during the pandemic, all of those functions had to adapt to a new situation. The neurosurgical service and training were no exception. Efforts had to be made to keep the system running.

Several publications have proposed and discussed the management of neurosurgical service and training to cope with stressful situations, especially the COVID-19 pandemic. Most of the papers have come from developed countries in which facilities and resources are different from those in LMICs. ${ }^{6-10}$ This article focuses on how a tertiary referral hospital in the epicenter of the storm is coping with the situation. We describe the impact of the outbreak, the university and hospital policies and actions for the neurosurgical service and training programs during the outbreak, and the contingency plan for future reference on preparedness for service and education.

\section{Methods}

The data on confirmed COVID-19 cases were collected from several official databases, including the published database of the Indonesian Ministry of Health (https://data. kemkes.go.id/covid19/index.html), The East Java Government Against COVID-19 database (http://infocovid19. jatimprov.go.id/), The Portal of Indonesian COVID-19 Taskforce (https://covid19.go.id/), and COVID-19 Dashboard by the Center for Systems Science and Engineering (CSSE) at Johns Hopkins University.

The hospital clinical data between January 1, 2020, and June 14, 2020, were retrieved from the DSAGH Hospital Information System database. We included data from the 3 months prior to the outbreak to give the reader a clearer picture of the impact of the outbreak. Fourteen full-time neurosurgeons cover the service with subspecialties (trauma, pediatric, oncology and skull base surgery, cerebrovascular, spine surgery, and functional). The academic center included 40 neurosurgical residents. During the outbreak, only procedures that were necessary to save life were allowed. The urgency of life-saving procedures was categorized as emergency and urgent. Emergency cases were defined as cases that needed immediate transfer to the emergency operating room (head or spinal injury, acute hydrocephalus, hemorrhagic stroke, or intracranial hypertension with signs of impending brain herniation). Urgent cases were spared for hydrocephalus without increased intracranial pressure, progressive myelopathy, cerebrovascular procedures without intracranial hypertension, and interventional pain management for disabling pain. The urgent cases were scheduled within 1 day to 1 week after admission.

The university and hospital policies were obtained from the dean's office and the board of directors of DSAGH. The provincial government's regulations were downloaded from the government's official site. Guidelines and protocols of the neurosurgical service during the pandemic were also gathered from the Indonesian Neurosurgical Society.

\section{Results \\ COVID-19 Case Progress in Indonesia}

By the 2nd week of June 2020, the Indonesian government had performed a polymerase chain reaction (PCR) swab test on 514,287 specimens from 322,933 people. There were 38,277 confirmed cases of COVID-19, with 14,531 recovered cases and 2134 cases of death. The case fatality rate was sloping downward from around $9 \%$ to $5 \%$ in 2 months, and the death rate was 8 persons per 1 million population. The new case findings increased from 300 cases per day on average in April/May to 500 cases per day in June. The increasing number of recovered cases followed the latest confirmed cases.

\section{COVID-19 Case Progress in East Java and Surabaya}

East Java province was the region with the highest COVID-19 cases in Indonesia, and the cases were distributed unevenly in 38 cities and towns. The first confirmed cases of COVID-19 infection in East Java were detected on March 20, 2020. By the 2nd week of June 2020, East Java province had recorded 5001 cumulative active cases, whereas Jakarta, in comparison, had documented 4334 cumulative active cases. There was a total of $7780 \mathrm{cu}-$ mulative confirmed cases, 2254 recovered cases, and 617 deaths. The age distribution data showed that the highest percentage of confirmed cases came from people 40-49 years old (23\%), followed by those who were $50-59$ years (21\%) and above 60 years (20\%). Diabetes mellitus and hypertension were the predominant comorbidities of patients treated for COVID-19 infections. The daily average of new cases increased from less than 50 cases in April 2020 to 150 cases by the 2 nd week of June 2020. A rapid spurt of the disease pushed the East Java provincial government to apply a large-scale social restriction regulation that was approved by the Indonesian Ministry of Health. The regulation was ended by the end of the 1st week of June and was not continued.

Surabaya had the highest number of confirmed cases 


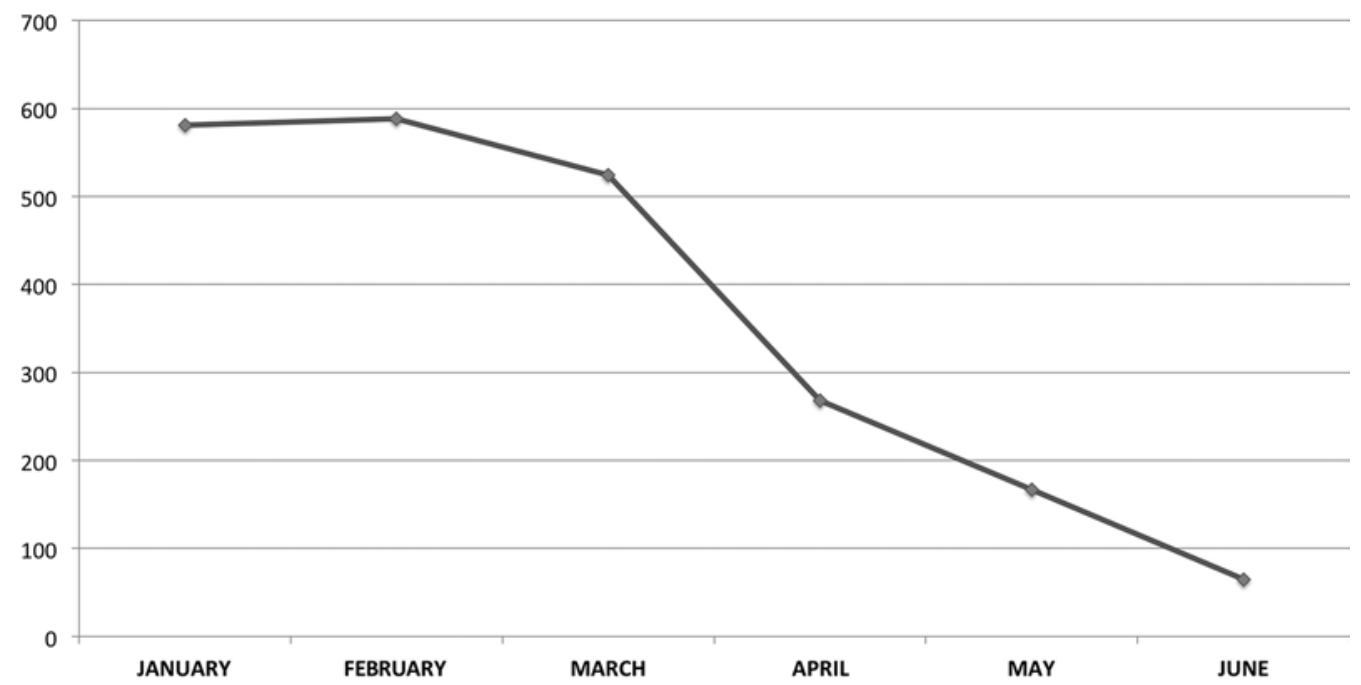

FIG. 1. The number of patients who visited the neurosurgery outpatient clinic at the DSAGH. The data included the impact of COVID-19 in Surabaya starting in April 2020. The data from the previous typical months were presented as a comparison.

among the cities and towns in East Java province. The city recorded 4014 cumulative active cases with 1269 recovered cases and 317 death cases.

\section{Clinical Data on Neurosurgical Service}

DSAGH is a nonprofit government-owned hospital. The impact of the COVID-19 outbreak forced hospital management to employ new protocols for providing healthcare. The neurosurgical service was affected as much as other specialty services. The impact of the new protocol involved a reduction in the number of outpatient clinics and surgical procedures (especially elective surgeries). The outpatient clinic visits decreased from 25-30 patients per day to 10 patients per day (Fig. 1). A patient who need- ed an urgent visit was allowed to visit the clinic, such as one needing an early postoperative visit or a patient with neurological deterioration or new complaints.

DSAGH had two separate buildings in which to perform an emergency operation or elective/urgent surgery. An emergency procedure was performed in the emergency building, and urgent or elective surgery was performed in the central surgical building. The number of neurosurgical procedures was also affected by the pandemic. Monthly surgical procedures decreased to roughly $50 \%$ of the ordinary volume (Fig. 2). Pediatric and neurovascular surgery dominated the surgical procedures in both emergency and urgent settings (Fig. 3). The institution of a large-scale social restriction reduced traffic activity, leading to a low number of trauma cases. Hospital restrictions and patient

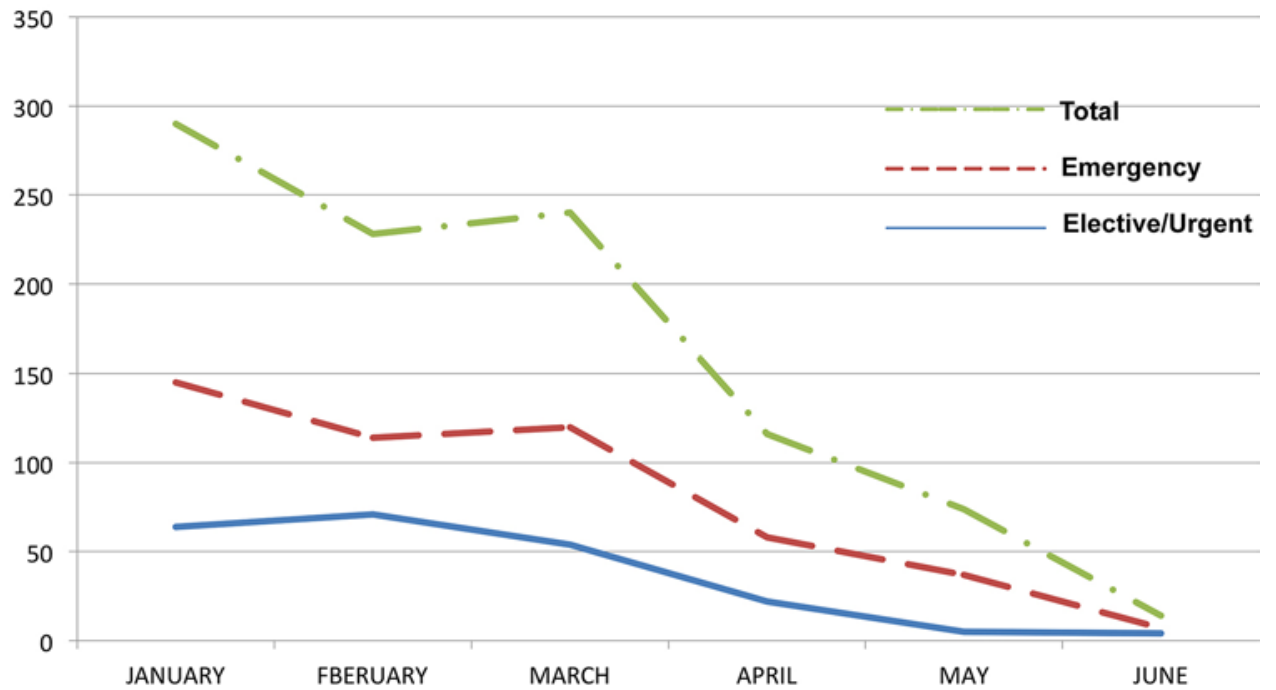

FIG. 2. The number of elective/urgent and emergency neurosurgical procedures performed between January 1,2020 , and the 2 nd week of June 2020 at DSAGH. 


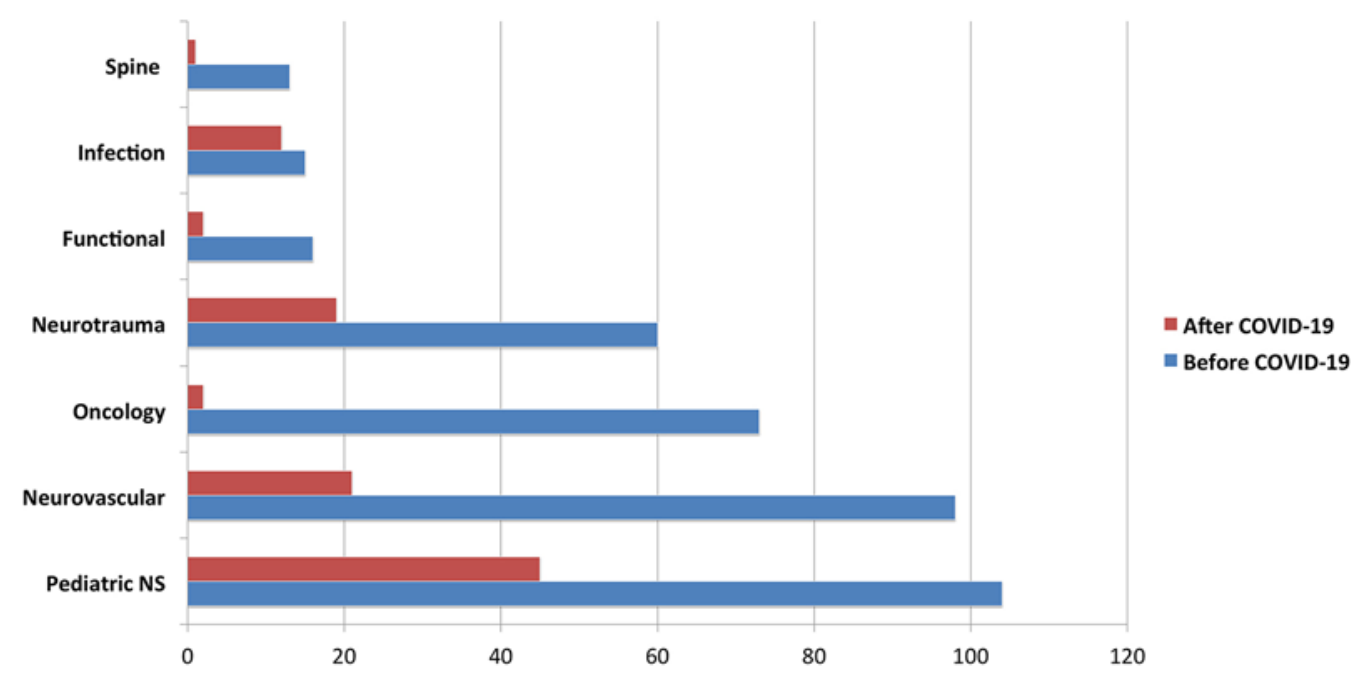

FIG. 3. The number of procedures based on subspecialties that was performed at DSAGH. Blue bars reflect the period before the COVID-19 outbreak (data from January to March 2020), and the red bars show the data for after the COVID-19 outbreak in Surabaya (April 2020 and afterward). NS = neurosurgery.

fears about coming to a red-zone hospital also contributed to the declining rate in cases.

So far, we have had 8 neurosurgical patients positive for COVID-19. We detected the COVID-19 prior to surgery in 6 of these patients ( 3 pediatric, 1 vascular, 1 trauma, and 1 spine case), and 2 previously negative patients (trauma cases) developed postoperative COVID-19-related pneumonia. Five patients died ( 2 pediatric, 2 trauma, and 1 spine case), 2 patients (1 pediatric and 1 trauma case) recovered, and 1 vascular patient is critically ill. All procedures on emergency COVID-19 patients were conducted with proper personal protective equipment (PPE) in a designated operating room.

\section{Impact on Neurosurgical Residency Training}

The reduction in the number of clinic visits, inpatients, and surgical cases had a direct impact on resident case log and experience. Restructuring and reorganizing residency training in the rotation setting further reduced clinical exposure. On the other hand, new educational tools and opportunities were introduced by managing digital educational webinars, teleconferences, and access to many international webinars that had been barely available before. Those online resources found popularity not only among residents but also among the attending physicians.

In addition to the educational impact, COVID-19 also took a toll on residents' welfare. Two of our neurosurgery residents with positive PCR swab test results just recovered after 2 weeks of treatment in a special isolation ward for infectious disease.

The residency program director reorganized the residents for service in 10-20 schemes (Fig. 4). The residents worked for 10 days, including in-hospital emergency calls, outpatient clinics, and the neurosurgical ward. After a 10-day service, they were given 20 days off-hospital in self-isolation and worked from home. This scheme gave the residents ample time to improve their knowledge and prepare for the neurosurgical board examination. The hos- pital also benefited by reducing the use of PPE and saving the hospital budget.

\section{Discussion}

We are now facing the WHO's phase 6 of the pandemic. ${ }^{11}$ The number of confirmed cases is increasing at a constant rate, which is parallel to the testing rate. Although the number of tests was increasing, Indonesia remained among the countries with a low testing rate (25 tests per 1 million population).$^{12}$ The low-testing-rate countries have continued to contribute to epidemiological repercussions and reflect the "iceberg phenomenon" of the outbreak. This phenomenon appears as decreasing case fatality rates and mortality rates with the number of detected cases increasing, especially cases with mild symptoms. ${ }^{13}$

\section{Neurosurgical Service: Impact, Action, and Plan}

The impact of COVID-19 on the neurosurgical service was real and ran parallel to the government and hospital board of directors' regulation. In Surabaya, there were 17 hospitals that provided neurosurgical services as a system, with DSAGH as the biggest hospital. The climbing number of COVID-19 cases in Surabaya warranted all hospitals in the system, including DSAGH, to serve as a tertiary referral hospital, to reorganize, and to restructure their resources to receive more COVID cases and reduce the number of nonemergency patients. However, the authority did not employ a centralized system (hub and spoke) for the neurosurgical service, as reported in other countries..$^{14}$ Despite the noncentralized strategy, the significant reduction in surgical cases was evident across the system. The situation contradicts that of Jean et al., who concluded that the neurosurgical services in LMICs were less affected by the COVID-19 pandemic. ${ }^{15}$ In early March 2020, the hospital had enough isolation rooms to accommodate COVID-19 patients. Because of the increasing cases, the isolation and monitoring rooms for 

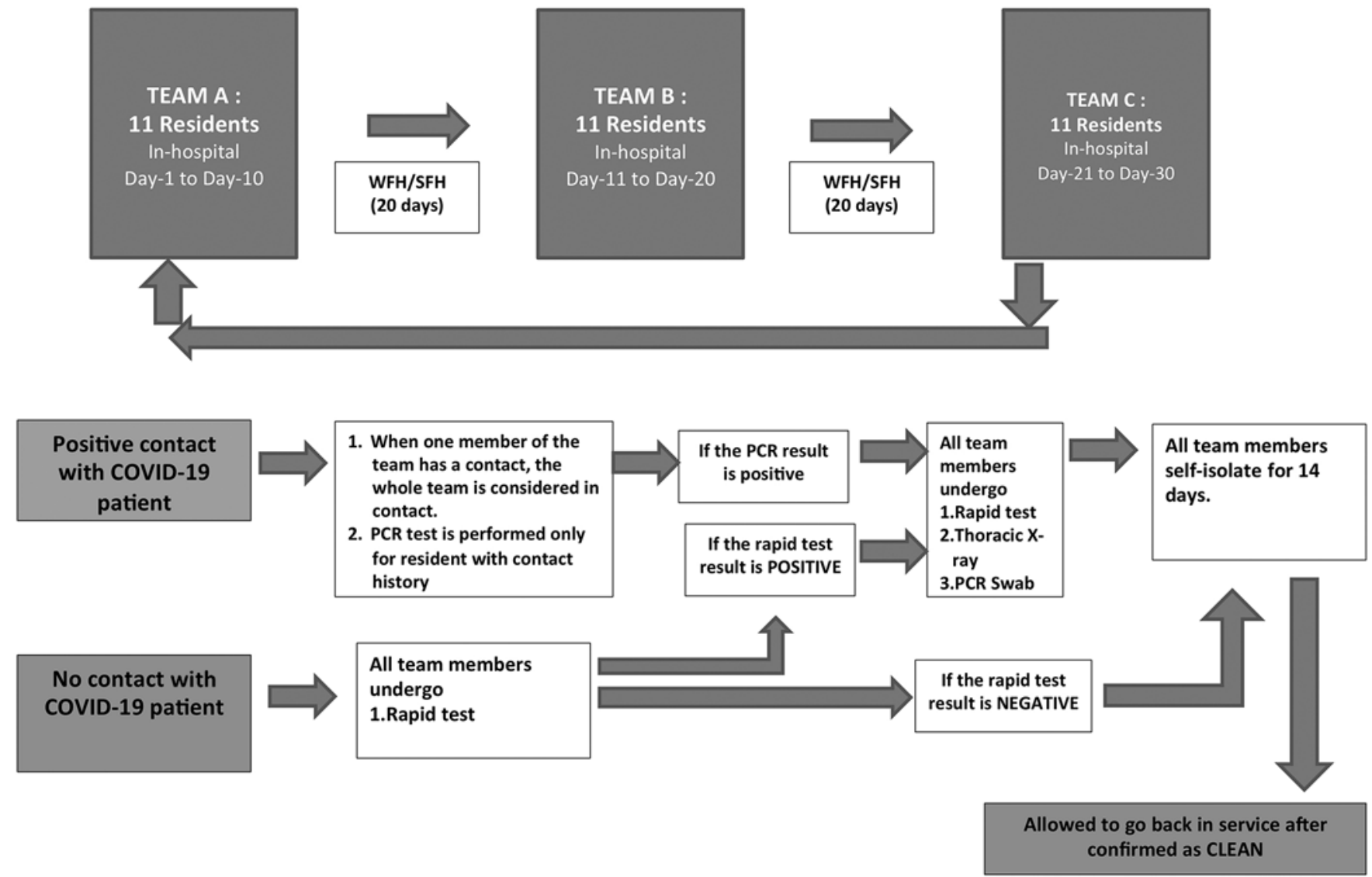

FIG. 4. The scheme of the resident's clinical rotation for neurosurgical service during the COVID-19 pandemic. The residents were split into three teams. Each team conducted clinical work for 10 days. At the end of the 10-day neurosurgical service, the team members were screened according to the hospital protocol. For the next 20 days, they worked or studied from home. SFH = study from home; $\mathrm{WFH}=$ work from home.

COVID-19 patients grew to 12 by the 2 nd week of June 2020. The consequences of room reorganization were a capacity reduction of the surgical ward and ICU for elective surgery. On the other hand, we followed the recommendation of the Indonesian Society of Neurological Surgeons to limit elective surgery. ${ }^{16}$ The policy also agreed with the recommendation of the neurosurgical service algorithm proposed by Burke et al., which put our hospital in the "red zone" in terms of the COVID-19 case surge level. ${ }^{8}$ We were aware that it might increase the waiting time and list. Patients with progressive neurological deterioration were considered as emergency or urgent cases and were treated according to the COVID-19 screening for surgical candidates.

At all hospital entry points (emergency room, admission center, and outpatient clinics), screening for COVID-19 infection risk was applied to all incoming patients. The DSAGH scoring for COVID-19 infection risk (Table 1) categorized the patient as low (score 4 or less), moderate (score 5-19), or high (score 20 or more) risk. The patient who fell into a high-risk category underwent a PCR test and subsequent thoracic radiology examination. The moderate-risk patient took a rapid test for COVID-19. A positive rapid test result had to be confirmed with the COVID-19 PCR nasopharyngeal swab test (PCR swab test). All patients with positive PCR swab tests followed the surgical protocol for confirmed cases of COVID-19. Low-risk patients might proceed to standard surgical procedures without any test for COVID-19.

Proper PPE was enforced for all neurosurgical activities in the clinic, ward, and operating room. In the early phase of the outbreak, comprehensive training was conducted to clean, store, and check PPE for any defect. The standard PPE for use in the neurosurgical setting was a properly fitted N95 mask, face shield, goggles, cap, full-body water-resistant gown, waterproof boots, and double gloves. We had no powered air-purifying respirator (PAPR) sets. Three operating rooms with negative pressure were available for emergency surgery. Designated rooms were provided for donning and doffing of PPE. Patient visits to the neurosurgery outpatient clinic were also limited. A patient who needed an urgent or emergency procedure was directed to the emergency room. The first or second clinic visit after surgery was allowed. The next clinic visit was determined after prior communication with the physician via chat application or phone. The patients and their family obtained guidance from the physician on what to observe and how to mitigate events.

Telemedicine has been proposed as a new avenue for patient continuity of care during the pandemic. Its imple- 
TABLE 1. DSAGH scoring system for COVID-19 infection risk screening

\begin{tabular}{|c|c|}
\hline Variable & Score \\
\hline Major criteria: 1 or more findings of major criteria & 20 \\
\hline \multicolumn{2}{|l|}{ a. History of unprotected contacts w/ COVID-19 patient \& show 1 or more minor signs } \\
\hline \multicolumn{2}{|l|}{ b. Bilat basal pneumonia on thoracic radiograph } \\
\hline \multicolumn{2}{|l|}{ c. Bilat ground-glass opacification on thoracic CT scan } \\
\hline \multicolumn{2}{|l|}{ Minor criteria } \\
\hline 1. Positive history of 1 of the following: & 4 \\
\hline \multicolumn{2}{|l|}{ a. Working at or attending a crowd/high-risk environment (hospital, market, airport, gathering, party, etc.) } \\
\hline \multicolumn{2}{|l|}{ b. Living or commuting to contaminated area or positive case in neighborhood } \\
\hline 2. Positive signs of 1 of the following: & 4 \\
\hline \multicolumn{2}{|l|}{ a. Fever w/in last 14 days } \\
\hline \multicolumn{2}{|l|}{ b. Anosmia } \\
\hline \multicolumn{2}{|l|}{ c. Respiratory tract signs (cough, flu-like signs, shortness of breath) } \\
\hline \multicolumn{2}{|l|}{ d. Gastrointestinal signs (diarrhea, nausea, vomiting, abdominal pain) } \\
\hline 3. History of diabetes mellitus, hypertension, chronic kidney disease, autoimmune disease, heart disease, obesity, pregnancy & 1 \\
\hline 4. White blood cell count $<5000$ & 1 \\
\hline 5. Neutrophil lymphocyte ratio $>3.5$ & 1 \\
\hline 6. Absolute lymphocyte count $<1100$ & 1 \\
\hline 7. Platelet count $<180,000$ & 1 \\
\hline 8. C-reactive protein: 5 times higher than normal & 1 \\
\hline 9. Thoracic radiographic abnormalities (unilat or bilat nonbasal pneumonia) & 1 \\
\hline 10. Unprotected contact w/ COVID-19 patient & 10 \\
\hline
\end{tabular}

Low risk, score 4 or less; moderate risk, score 5-19; high risk, score 20 or more.

mentation in more developed countries with an established healthcare system and a better social background supported by better infrastructure might differ from that in LMICs. ${ }^{17,18}$ In fact, its implementation in LMICs can present some difficulties, including in terms of the technology, the workforce, the patient's or their family's socioeconomic background, the legal issues regarding the patient's privacy, and the regulation regarding the insurance claim or hospital payment.

\section{Neurosurgical Education: Impact, Action, and Plan}

The significant reduction in neurosurgical service unequivocally impacted the resident's clinical exposure and experience. The reorganization of the resident's shift added another limitation. Despite those limitations, there were several opportunities to improve the resident's skills in areas other than neurosurgery. Crisis management, handling a difficult situation, and leadership skills were among the skill sets that needed to be honed for future independent practice. ${ }^{9}$

On the other hand, the pandemic opened up new educational tools for students and residents to be part of the digital generation. Webinars, teleconferences, and digital learning from online resources grew exponentially. Teleconference meetings were held on a scheduled basis to replace the in-person meetings. It had an impact on a resident's knowledge, but it also opened up an invaluable opportunity for residents to discuss cases with neurosurgical giants and experts worldwide. Nevertheless, digital re- sources could not replace the real clinical and surgical experience where the complexities build the learning curve.

The university instituted nonphysical meetings for undergraduate students that rotated in clinical electives. It meant that the students had diminished clinical exposure in various areas of medicine during their medical school. To mitigate the situation, the dean of the faculty of medicine, clinical program for undergraduate student program director, and residency program director deployed a new rotation system that split all clinical elective rotations and residency rotations into two parts. The first part has been in effect during the pandemic phase of COVID-19 to cover the students' knowledge and simulated experience. The second part is expected to occur after the hospital environment is considered safe for "normal" educational purposes (Fig. 5).

\section{Conclusions}

The academic tertiary referral hospital of an LMIC was affected by the implementation of a crisis protocol to curb the COVID-19 pandemic. The neurosurgery service experienced a significant reduction in cases. The university and program directors had to adapt to an off-campus and off-hospital policy for neurosurgical residents and undergraduate students. Reorganization of residents to provide service followed the safety protocol instituted by the university and hospital. The digital environment found popularity during the outbreak to support the educational process. 


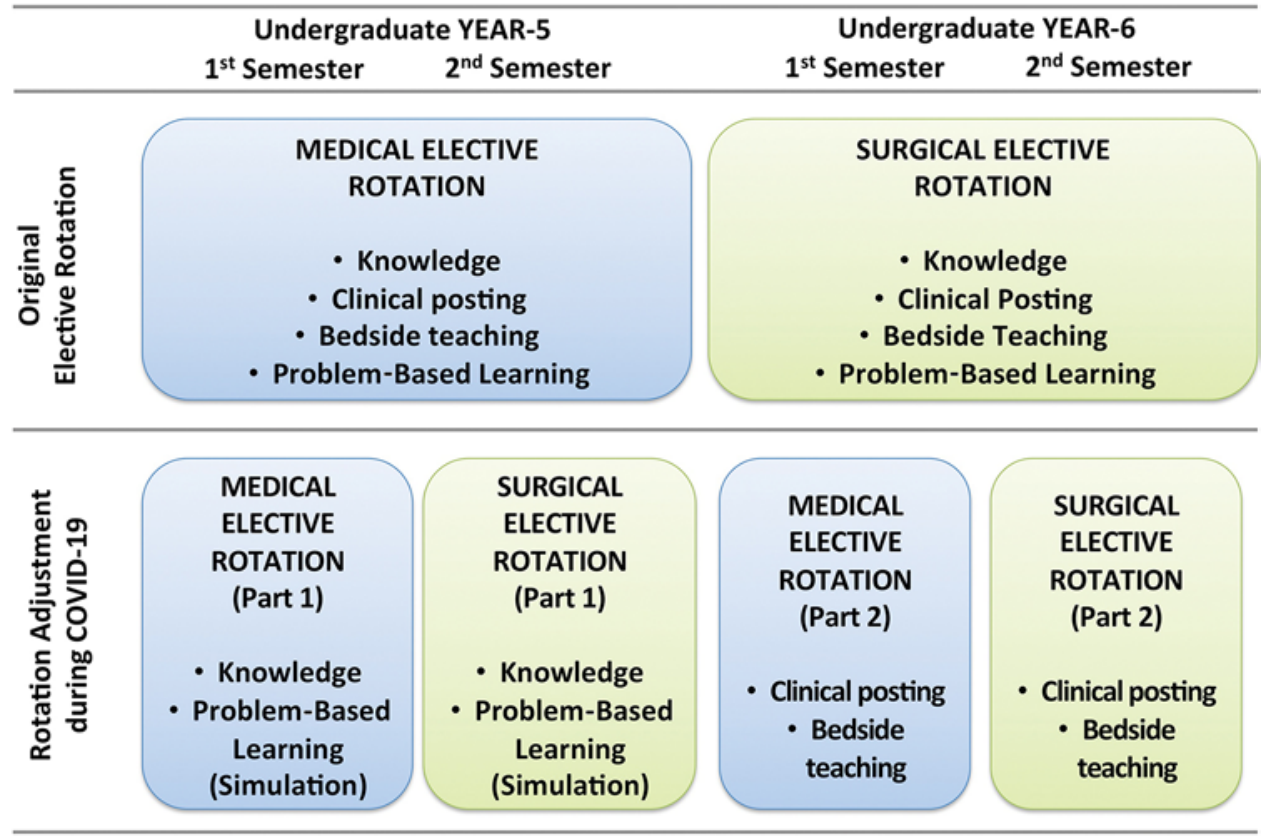

FIG. 5. Elective rotation adjustment for medical undergraduate students during the COVID-19 pandemic.

\section{References}

1. Indonesian Ministry of Health. Dua Pasien Positif Covid-19 Dirawat di RSPI Sulianti Saroso. Indonesian Ministry of Health; 2020. Accessed October 12, 2020. https://www. kemkes.go.id/article/view/20030200009/dua-pasien-positifcovid-19-dirawat-di-rspi-sulianti-saroso.html

2. Government of East Java Province. Perpanjangan Pemberlakuan Pembatasan Sosial Berskala Besar Dalam Penanganan Corona Virus Disease 2019 (Covid-19) Di Wilayah Kota Surabaya, Kabupaten Sidoarjo, Dan Kabupaten Gresik. Decree of the Governor of East Java Province No. 188/219/ KPTS/013/2020. Government of East Java Province; 2020.

3. Indonesian Ministry of Health. Pedoman Pembatasan Sosial Berskala Besar Dalam Rangka Percepatan Penanganan Corona Virus Disease 2019 (Covid-19) (Guidelines for large-scale social restrictions in order to accelerate handling of COVID-19). Permenkes 9/2020. Indonesian Ministry of Health; 2020.

4. Government of East Java Province. Pemberlakuan Pembatasan Sosial Berskala Besar Dalam Penanganan Corona Virus Disease 2019 (Covid-19) Di Wilayah Kota Surabaya, Kabupaten Sidoarjo, Dan Kabupaten Gresik. Decree of the Governor of East Java Province No. 188/202/KPTS/013/2020. Government of East Java Province; 2020.

5. Indonesian Ministry of Health. Penetapan Rumah Sakit Rujukan Penanggulangan Penyakit Infeksi Emerging Tertentu (Referral hospital for management of specific emerging infectious disease). Decree of the Indonesian Minister of Health No. KH.01.07/MENKES/169/2020. Indonesian Ministry of Health; 2020.

6. Wen J, Qi X, Lyon KA, et al. Lessons from China when performing neurosurgical procedures during the coronavirus disease 2019 (COVID-19) pandemic. World Neurosurg. 2020; 138:e955-e960.

7. Lee ZD, Chyi Yeu DL, Ang BT, et al. Editorial. COVID-19 and its impact on neurosurgery: our early experience in Singapore. J Neurosurg. 2020;133(1):24-25.

8. Burke JF, Chan AK, Mummaneni V, et al. Letter: The coro- navirus disease 2019 global pandemic: a neurosurgical treatment algorithm. Neurosurgery. 2020;87(1):E50-E56.

9. Low JCM, Visagan R, Perera A. Neurosurgical training during COVID-19 pandemic: British perspective. World Neurosurg. 2020;142:520-522.

10. Low TY, Hartman M, Chee CYJ, et al. Restructuring the surgical service during the COVID-19 pandemic: experience from a tertiary institution in Singapore. Am J Surg. 2020; 220(3):553-555.

11. World Health Organization. Current WHO phase of pandemic alert for pandemic (H1N1) 2009. World Health Organization; 2020. Accessed October 12, 2020. http://www.who.int/ csr/disease/swineflu/phase/en/

12. Hasell J, Mathieu E, Beltekian D, et al. Coronavirus (COVID-19) testing. Our World in Data; 2020. Accessed October 12, 2020. https://ourworldindata.org/coronavirus-testing

13. Baquero C, Casari P, Anta AF, et al. Measuring icebergs: using different methods to estimate the number of COVID-19 cases in Portugal and Spain. medRxiv. Preprint posted online April 23, 2020. doi:10.1101/2020.04.20.20073056

14. Cenzato M, DiMeco F, Fontanella M, et al. Editorial. Neurosurgery in the storm of COVID-19: suggestions from the Lombardy region, Italy (ex malo bonum). J Neurosurg. 2020; 133(1):33-34.

15. Jean WC, Ironside NT, Sack KD, et al. The impact of COVID-19 on neurosurgeons and the strategy for triaging non-emergent operations: a global neurosurgery study. Acta Neurochir (Wien). 2020;162(6):1229-1240.

16. Indonesian Society of Neurological Surgeons. Rekomendasi Pelaksanaan Pelayanan Bedah Saraf Dalam Masa Pandemi COVID-19 di Indonesia (Recommendation for managing neurosurgical service during COVID-19 pandemic in Indonesia). Indonesian Society of Neurological Surgeons; 2020. Accessed October 12, 2020. http://www.ins.or.id/assets/uploads/ news/d67aa-final_perspebsi-covid_21.04.2020.pdf

17. Blue R, Yang AI, Zhou C, et al. Telemedicine in the era of coronavirus disease 2019 (COVID-19): a neurosurgical perspective. World Neurosurg. 2020;139:549-557.

18. Daggubati LC, Eichberg DG, Ivan ME, et al. Telemedicine 
for outpatient neurosurgical oncology care: lessons learned for the future during the COVID-19 pandemic. World Neurosurg. 2020;139:e859-e863.

\section{Disclosures}

The authors report no conflict of interest concerning the materials or methods used in this study or the findings specified in this paper.

\section{Author Contributions}

Conception and design: Suryaningtyas, Wahyuhadi, Turchan, Subagio, Bajamal. Acquisition of data: Suryaningtyas, Subagio, Parenrengi, Apriawan. Analysis and interpretation of data:

Suryaningtyas, Wahyuhadi, Parenrengi, Al Fauzi. Drafting the article: Suryaningtyas, Wahyuhadi, Turchan. Critically revising the article: all authors. Reviewed submitted version of manuscript: all authors. Approved the final version of the manuscript on behalf of all authors: Suryaningtyas. Study supervision: Suryaningtyas, Bajamal.

\section{Correspondence}

Wihasto Suryaningtyas: Universitas Airlangga Faculty of Medicine-Dr. Soetomo Academic General Hospital, Surabaya, Indonesia.wihasto-s@fk.unair.ac.id. 